\title{
The Implementation Of 3S (SDKI, SIKI, SLKI) to The Quality Of Nursing Care Documentation In Hospital's Inpatient Rooms
}

\author{
Wiwin Sulistyawati*, Susmiati \\ Faculty of Health Sciences, Kadiri University, Indonesia \\ *wiwin.sulistyawati@unik-kediri.ac.id
}

\begin{abstract}
Nursing care documenting is evidence of the recording of nurses containing the status or care nurses provide to patients. The implementation of nursing documentation has not been optimal, seen from the lack of complete nursing documentation, and still varies the nursing documentation contents. Poor documentation has the effect of miscommunication between nurses and other health professions, which will result in a deterioration in the quality of nursing services. The implementation of 3S (SDKI, SIKI, and SLKI) is a benchmark used as a guideline for the enforcement of nursing diagnosis, nursing intervention, and a nursing outsider to provide safe, effective, and ethical nursing care. This study aims to analyze the implementation of $3 \mathrm{~S}$ on the quality of documentation in hospital inpatient rooms. Research design correlation analysis with the cross-sectional approach. The research sample of implementing nurses in hospital inpatient rooms who have implemented 3S. Sampling techniques use sampling quotas. Respondents were given informed consent, dissemination of questionnaires about the implementation of 3S), and the evaluation of the documentation of Instrument A. The health department researcher has developed through a google form. Data tested using the Chi-Square test. Based on statistical test results obtained, p-value $=0.001<\alpha 0.005$ so that $\mathrm{H} 0$ is rejected $\mathrm{H} 1$ is accepted. It means there is a relationship of application of $3 \mathrm{~S}$ to the quality of nursing care documentation in hospital inpatient rooms. Based on the results of this study, the Head of Nursing is expected to implement SDKI, SIKI, and SLKI to improve the quality of nursing care documentation, which will have an impact on improving the quality of nursing services.
\end{abstract}

Keywords: 3S (SDKI, SIKI, SLKI), Quality of Documentation of Nursing Care, Hospital Inpatient Room 


\section{STRADA Jurnal Ilmiah Kesehatan}

DOI: $10.30994 /$ sjik.v9i2.468

ISSN: 2252-3847 (print); 2614-350X (online)

Vol.9 No.2 November 2020 Page.1323-1328

\section{BACKGROUND}

Documenting quality nursing care is useful for improving nursing care. It can be seen through reports and patient responses to nursing interventions (Jefferies D., 2010). Hospitals documenting is useful to improve hospital accreditation standards, communication tools between health professions, quality service indicators, proof of responsibility and responsibility of nurses, data sources, and research facilities (Jefferies, D., Johnson, M., Nicholls, D., and Lad, 2012). The implementation of nursing care documentation in the Hospital has not been optimal. It is seen from the incomplete documentation of nursing care. The completeness of the documentation carried out by nurses is mostly less than $85 \%$, meaning most are still incomplete $(71,6 \%)$. As for $90 \%$ assessment activities, 85\% nursing diagnosis, 74\% action planning, 70\% nursing action, $75 \%$ evaluation, and $66 \%$ development record (Siswanto, Tutik, \& Hariyati, 2013).

Implementation of nursing documentation in criteria both $47.4 \%$ and nurses who complete nursing documentation by 57.2\% (Noorkasiani, Gustina, \& Maryam, 2015). Poorly qualified, ineffective, and efficient documentation impacts miscommunication between nurses and other professions (Braaf, S., Manias, E., \& Riley, 2011). Factors related to the completeness of nursing care documentation include workload, workload, and training, the most dominant factors affecting the completeness of documentation are training and workload. Documentation training for nurses is useful to improve nursing care documentation (Siswanto et al., 2013). It is hoped that the field of care can complement nursing documentation in the same format, allow nurses to continue their studies, and take nursing care training and exchange information or ideas between nurses (Noorkasiani et al., 2015).

The application of $3 S$ (Indonesian Nursing Diagnosis Standard (SDKI), Indonesian Nursing Intervention Standards (SIKI), and Indonesian Nursing Outcome Standards (SLKI)) in inpatient rooms contributes to improving the quality of nursing care documentation. The focus of increased knowledge through training improves nursing documentation conducted by nurses (Jefferies, D., Johnson, M., Nicholls, D.,\& Lad, 2012). SDKI, SIKI, and SLKI are benchmarks for enforcement of nursing diagnosis, nursing intervention, and outside nursing to provide safe, effective, and ethical nursing care (SDKI, 2017).

Based on the study results with the nursing department of the hospital in East Java, not all hospitals implement $3 S$ (SDKI, SIKI, and SLKI) in the documenting of nursing care. Some hospitals in East Java that have implemented 3S are Dr. Soetomo Hospital, RSSA Malang, Dr. Soedono Madiun Hospital, and Dr. Sayidiman Magetan Hospital. Based on that background, researchers are interested in researching the implementation of 3S (SDKI, SIKI, and SLKI) to the quality of nursing care documentation in hospital inpatient rooms.

\section{METHODS}

The design of this study is a correlation analysis with a cross-sectional approach. This research site is a hospital inpatient room in East Java that has implemented SDKI, SIKI, and SLKI. The study was conducted in June - September 2020. This study's population was part of the implementing nurses in hospital inpatient rooms in East Java who were taken through simple random sampling. Independent Variables are $3 \mathrm{~S}$ Implementation (SDKI, SIKI, SLKI), while Variable dependent is the quality of nursing care documentation. The research instrument uses the Department of Health Documentation Evaluation questionnaire sheet (Instrument A) developed by the researcher, and the $3 \mathrm{~S}$ 


\section{STRADA Jurnal Ilmiah Kesehatan}

DOI: $10.30994 /$ sjik.v9i2.468

ISSN: 2252-3847 (print); 2614-350X (online)

Vol.9 No.2 November 2020 Page.1323-1328

implementation questionnaire (SDKI, SIKI, and SLKI) developed by the researcher. The research was done by disseminating questionnaires through google forms. Respondents signed informed consent, filled out a questionnaire on google form, and sent back the google form questionnaire.

\section{RESULT}

The results of univariate and bivariate studies are shown in the table below. Characteristics of Respondents based on age, Marital Status, Length of Work and Education Level.

Table 1. Characteristics of Respondents Based on Age, Marital Status, Length of Work and Education Level.

\begin{tabular}{ccc}
\hline Characteristics & Total (n) & Percentage (\%) \\
\hline Respondent's Age & & 16,7 \\
\hline$<25$ years old & 14 & 75,0 \\
\hline $25-40$ years old & 63 & 8,3 \\
\hline$>40$ years old & 7 & 25 \\
\hline Marital Status & 21 & 66,7 \\
\hline Unmarried & 56 & 83 \\
\hline Married & 7 & 16,7 \\
\hline Widow/ Widower & & 33,3 \\
\hline Length of Work & 14 & 50 \\
\hline$<5$ years & 28 & 41,7 \\
\hline 5- 10 years & 42 & 54,8 \\
\hline$>10$ years & & 3,6 \\
\hline Education Level & 35 & \\
\hline D3 in Nursing & 46 & \\
\hline Undergraduate in & & \\
Nursing (Nurse) & 3 & \\
\hline Post Graduate in & & \\
Nursing & & \\
\hline
\end{tabular}

Based on the table above, it can be interpreted that the majority of respondents or 63 respondents $(75 \%)$ are at 25 - 40 years old, 56 respondents $(66.7 \%)$ are married, and 46 respondents $(54.8 \%)$ are having their undergraduate degree in nursing. Furthermore, half of respondents or 42 respondents $(50 \%)$ have a working length of 5-10 years.

Characteristics of Respondents Based on The Results of 3S Implementation Questionnaire (SDKI, SIKI, SLKI) and Quality of Nursing Care Documentation 


\section{STRADA Jurnal Ilmiah Kesehatan}

DOI: $10.30994 /$ sjik.v9i2.468

ISSN: 2252-3847 (print); 2614-350X (online)

Vol.9 No.2 November 2020 Page.1323-1328

Table 2. Characteristics of Respondents Based on The Results of $3 \mathrm{~S}$ Implementation Questionnaire (SDKI, SIKI, SLKI) and Quality of Nursing Care Documentation

\begin{tabular}{ccc}
\hline Characteristics & Total (n) & Percentage (\%) \\
\hline 3S Implementation & & \\
\hline Good & 51 & 60,7 \\
\hline Poor & 33 & 39,3 \\
\hline $\begin{array}{c}\text { Quality of Nursing Care } \\
\text { Documentation }\end{array}$ & & \\
\hline Good & 70 & 83,3 \\
\hline Poor & 14 & 16,7 \\
\hline
\end{tabular}

Based on the table above, it can be interpreted that the majority of respondents or 51 respondents $(60.7 \%)$ implement $3 \mathrm{~S}$ well, and have a good quality of nursing care documentation which is as many as 70 Respondents (83.3\%).

Table 3. The Relationship of $3 S$ Implementation (SDKI, SIKI, SLKI) with The Quality of Documenting nursing care in the Inpatient Room.

\begin{tabular}{ccccc}
\hline & \multicolumn{2}{c}{$\begin{array}{c}\text { Quality of } \\
\text { Documenting nursing } \\
\text { care }\end{array}$} & Total \\
\hline $3 \mathrm{~S}$ & Good & 48 & Poor & \\
\hline $\begin{array}{c}\text { Good } \\
\text { Implementation }\end{array}$ & Poor & 22 & 3 & 51 \\
\hline p-value & & 70 & 11 & 33 \\
\hline$\alpha=0,05$ & & $0,001 *$ & 14 & 84 \\
\hline
\end{tabular}

Based on Chi Square test results obtained p-value $=0.001<\alpha=0.005$, so Ho is rejected and $\mathrm{H} 1$ is accepted. It means that there is a relationship between the implementation of $3 \mathrm{~S}$ and the quality of nursing care documentation in the hospital inpatient room.

\section{DISCUSSION}

The Implementation of $3 S$ (SDKI, SIKI, SLKI) in Hospital Inpatient Rooms.

Based on the results of the study, most respondents $(60.7 \%) 3 \mathrm{~S}$ adequately. It is seen from the SOP about the implementation of $3 S$ (SDKI, SIKI, SLKI) in the Hospital where they work, there is already a SAK format that refers to SDKI, SIKI, and SLKI, and socialization about SDKI, SIKI, and SLKI although not all respondents get socialization. However, for evaluation and coaching activities on SDKI, SIKI, and SLKI were only carried out in some respondents $(65 \%)$. SDKI is a benchmark used as a guideline for the enforcement of nursing diagnosis to provide safe, effective, and ethical nursing care. SDKI includes definitions of nursing diagnosis, classification of nursing diagnosis, type of nursing diagnosis, nursing diagnosis component, and nursing diagnosis enforcement process (SDKI, 2017). SLKI includes definitions of the nursing outcome, outcome classification of nursing, outcome type of nursing, outcome type of nursing, outcome component of nursing, and nursing outcome implementation (SLKI, 2019). 


\section{STRADA Jurnal Ilmiah Kesehatan}

DOI: $10.30994 /$ sjik.v9i2.468

ISSN: 2252-3847 (print); 2614-350X (online)

Vol.9 No.2 November 2020 Page.1323-1328

Quality of Documentation of Nursing Care in Hospital Inpatient Rooms

Based on the study results, most respondents had a good quality of documentation of nursing care, which is as many as 70 respondents (83.3\%). The use of documentation instruments that do not comply with the standards may cause discrepancies in nursing care provided to affect documentation quality (Nursalam, Widodo, Wahyuni, \& Efendi, 2020). Factors that cause nursing documentation quality include documentation according to the nursing process, standardized terminology and documentation instruments, electronic documentation, and documentation instruments that vary according to nursing practices (De Groot et al., 2019). According to (Siswanto et al., 2013), the most dominant factors affecting the documentation's completeness are training and workload. There is a relationship between the working period, training, and workload with documenting completeness.

\section{The Relationship of $3 S$ Implementation (SDKI, SIKI, SLKI) with The Quality of Documenting nursing care in the Inpatient room.}

The chi-square test results obtained, $\mathrm{p}$-value $=0.001<\alpha=0.005$ meaning Ho was rejected, and $\mathrm{H} 1$ was accepted. It means a relationship between the application of $3 \mathrm{~S}$ and the quality of documentation in the hospital inpatient room. The documenting of nursing care is evidence of the recording and reporting of nurses in care records that are useful for the benefit of clients, nurses, and health teams in providing health services based on accurate and complete data in writing as the responsibility of nurses (Wahid, A. \& Suprapto, 2012). Nurses generally dislike documentation because it is complicated, timeconsuming, and varies between nurses. It is one of the factors that cause nursing documentation done by nurses to be inaccurate, complete, and accurate, which will later impact the deterioration of the quality of nursing services. Legally, documentation is written proof of a nurse in providing nursing care (Nursalam, 2012). Poorly qualified, ineffective, and efficient documentation impacts miscommunication between nurses and other professions (Braaf, S., Manias, E., \& Riley, 2011).

One way to improve nursing care is by documenting through training and implementation of $3 S$ (SDKI, SIKI, and SLKI). SDKI, SIKI, and SLKI are benchmarks used as guidelines for enforcement of nursing diagnosis, nursing intervention, and nursing outcomes to provide safe, effective, and ethical nursing care. The focus of increased knowledge through training improves nursing documentation conducted by nurses (Jefferies, D., Johnson, M., Nicholls, D., \& Lad, 2012). SDKI is a guide for nurses in enforcing nursing diagnosis, facilitating extraprofessional and interprofessional communication that impacts improving nursing care (SDKI, 2017). SIKI is a nurse's guide in drafting nursing interventions to create uniformity of terminology to describe the scope of nurses' interventions and increasingly show nursing contributions in the health service (SIKI, 2018). SLKI makes it easy for nurses to plan nursing care following the expected outdoors to meet the client's nursing needs as a whole unit so that all aspects of nursing care received by the client are optimal service, standardized nationally without ignoring the socio-cultural and spiritual values embraced by the client (SLKI, 2019)

\section{CONCLUSION}

Based on the study results, most respondents implemented $3 S$ (SDKI, SIKI, SLKI) well. The quality of documentation in the inpatient rooms at 4 Hospitals in East Java is mostly good. There is a relationship between the implementation of $3 S$ (SDKI, SIKI, SLKI) and the quality of documenting nursing care in hospital inpatient rooms in 4 hospitals in East Java. 


\section{STRADA Jurnal Ilmiah Kesehatan}

DOI: $10.30994 /$ sjik.v9i2.468

ISSN: 2252-3847 (print); 2614-350X (online)

Vol.9 No.2 November 2020 Page.1323-1328

It is expected that the nursing field creates a documenting format and SOP documenting that refers to SDKI, SIKI, and SLKI and the socialization of that format, thus improving the quality of nursing care documentation

\section{REFERENCES}

Braaf, S., MAnias, E., \& Riley, R. (2011). The role of documents and documentation in communication failure ecross the perioperative pathway: A literature review. Intrenational Journal of Nursing Studies, 48(8), 1024-1038.

Jefferies, D.,Johnson, M.,Nicholls, D.,\& Lad, S. (2012). A ward-based writing coach program to improve the quality of nursing documentation. Journal Nurse Education Today, 32, 647-651.

Jefferies D., J. M. and G. R. (2010). A meta-study of the essentials of quality nursing documentation. Int J Nurs Pract., 16, 112-124.

Noorkasiani, N., Gustina, G., \& Maryam, R. S. (2015). Faktor-Faktor yang Berhubungan dengan Kelengkapan Dokumentasi Keperawatan. Jurnal Keperawatan Indonesia, 18(1), 1-8. https://doi.org/10.7454/jki.v18i1.391

Nursalam. (2012). Manajemen Keperawatan Aplikasi dalam Praktek Keperawatan Profesional (Edisi 3). Jakarta: Salemba Medika.

Nursalam, N., Widodo, H., Wahyuni, E. D., \& Efendi, F. (2020). Development of perioperative care instruments based on SDKI SLKI SIKI in operating room. Systematic Reviews in Pharmacy, 11(6), 1029-1035. https://doi.org/10.31838/srp.2020.6.147

SDKI, T. P. P. (2017). Standar Diagnosis Keperawatan Indonesia : Definisi dan Indikator Diagnostik. (II). Jakarta: DPP PPNI.

SIKI, T. P. P. (2018). Standar Intervensi Keperawatan Indonesia: Definisi dan Tindakan Keperawatam (II). Jakarta: DPP PPNI.

Siswanto, L. M. H., Tutik, R., \& Hariyati, S. (2013). FAKTOR-FAKTOR YANG BERHUBUNGAN DENGAN KELENGKAPAN Pendahuluan Metode. 16(2), 77-84.

SLKI, T. P. P. (2019). Standar Luaran Keperawatan Indonesia: Definisi dan Kriteria Hasil Keperawatan. Jakarta: DPP PPNI.

Wahid, A. \& Suprapto, I. (2012). Dokumentasi Proses Keperawatan. Yogjakarta: Nuha Medika. 